\title{
BIO-MONITORING STUDY ON TROPOSPHERIC OZONE USING WHITE CLOVER AT BANGLADESH AGRICULTURAL UNIVERSITY FARMING AREA
}

\author{
M. T. Islam, M. A. Ashraf ${ }^{1}$ and M. A. Sattar \\ Department of Environmental Science, Bangladesh Agricultural University \\ Mymensingh-2202, Bangladesh
}

\begin{abstract}
A pot experiment was conducted at the field laboratory of the Dept. of Environmental Science, Bangladesh Agricultural University, Mymensingh to asses the visual ozone injury in white clover crops (Trifolium repens cv. Regal) started from May 13, 2007. Two genotypes of white clover were used of which one was ozone susceptible (NC-S) and the other was ozone resistant (NC-R). Each genotype was replicated into 20. The data on total plant dry matter harvested thrice at 28 days interval resulted in increasing biomass gradually in later harvests. The Monthly mean ozone values collected from passive ozone sampler during April to August'07 was recorded as 29, 35, 49, 28 , and $61 \mathrm{ppb}$ respectively, which seemed that ozone concentrations in the troposphere is increasing gradually in Bangladesh. The susceptible NC-S showed visual ozone injury symptom from very slightly $(0-1 \%)$ to slight $(1-5 \%)$ where as the resistant cultivar showed no visual injury symptom. The ozone susceptible cultivar generally produced comparatively less biomass than the resistant one at every harvest.
\end{abstract}

Key Words : Bio-monitoring, Tropospheric ozone, Plant biomass, White clover, Visual injury

\section{INTRODUCTION}

Tropospheric ozone $\left(\mathrm{O}_{3}\right)$ is the most widespread and phyto-toxic pollutant that frequently exceeds WHO (World Health Organisation) air quality guidelines for agricultural crops across many parts of the globe. Elevated $\mathrm{O}_{3}$ levels have been found to cause declines in the yield of many crop species, such as soybean and cotton (Fuhrer et al., 1997; Fuhrer and Booker, 2003). Such yield losses have been attributed to reduce photosynthetic rate (Lehnherr et al., 1997; McKee et al., 1997) and altered carbon allocation (Grantz and Yang, 2000) as well as an indirect effect of accelerated leaf senescence (Grandjean and Fuhrer, 1989).

$\mathrm{O}_{3}$ has also been shown to induce visible injury, which may, for example, reduce the economic value of leafy crops (Emberson et al., 2003), though such damage generally occurs after acute $\mathrm{O}_{3}$ exposures. It was also shown that $\mathrm{O}_{3}$ affects crop quality (e.g.,

1Department of Farm Structure, Bangladesh Agricultural University, Mymensingh-2202, Bangladesh 
nitrogen content of grains, tubers, etc. and nutritive quality of forage crops) though the direction of the effect is not always consistent between different quality aspects. For wheat, grain protein concentration has been found to increase, while protein production per unit ground area decreased with increasing $\mathrm{O}_{3}$ concentrations (Pleijel et al., 1999a). For potato, increasing $\mathrm{O}_{3}$ had a negative impact on tuber quality (Vorne et al., 2002); for subterranean clover (an important forage crop of Mediterranean Europe as well as other regions) elevated $\mathrm{O}_{3}$ was found to decrease nutritive quality for ruminant animals associated with $\mathrm{O}_{3}$ induced accelerated senescence (Sanz et al., 2005). Wang and Mauzerall (2004) estimated economic losses for wheat, rice, maize and soybean for China, South Korea and Japan and estimated economic losses at US\$ 5 billion, again using the 7 and 12 hour mean $\mathrm{O}_{3}$ metrics. These losses were represented by percentage yield losses of up to $9 \%$ for the cereal crops and 23 to $27 \%$ for soybean (a species recognized as very sensitive to $\mathrm{O}_{3}$ ).

There is a large body of evidence to suggest that considerable impacts are occurring at site-specific locations in South Asia (Wahid, 2003; Agrawal, 2003). Were similar reductions in productivity observed in these site-specific studies to be representative of major agricultural areas of the region, the implications for crop yield, the nutritional quality of staple crops and the livelihoods of subsistence farmers and those that depend on local food production could be dramatic. In short, food production in localized elevated $\mathrm{O}_{3}$ "hot spot" areas and the continued food security of the South Asian region as a whole could be severely compromised. In Bangladesh context, no basic data on ambient ozone has yet available. The use of huge amount of old vehicles in transport, the chimney of the industries and brickfields without charcoal filters, ever increasing use of CFCs in the households, etc. perhaps is increasing ozone level day by day.

Biomonitoring method now a day is becoming much popular indirect method to assess the air pollutant level in any location. The clover-clone method was initially developed in the humid subtropical climate of North Carolina, USA ( Heagle et al., 1994) and has been used extensively since 1996 by the UNECEs International Cooperative Programme on Effects of Air Pollution on Natural Vegetation and Crops (ICP Vegetation) in Europe and North America (Harmens et al., 2005). The method uses $\mathrm{O}_{3}$-sensitive and $\mathrm{O}_{3}$-resistant white clover genotypes (Trifolium repens $\mathrm{cv}$. Regal) and works on the principle that the difference in plant foliar injury as well as the biomass ratio between the $\mathrm{O}_{3}$-sensitive (NC-S) and $\mathrm{O}_{3}$-resistant (NC-R) clover genotypes can be directly related to the prevalent $\mathrm{O}_{3}$ concentrations during the exposure period. So the present research on "biomonitoring study on tropospheric ozone using white clover at Bangladesh Agricultural University farming area" is very essential to save the agriculture and insurance of food supply for the next generation.

\section{Objectives of the study}

1. To know the ozone concentrations in the troposphere at Bangladesh environment,

2. To show the effects of tropospheric ozone on plant biomass, and

3. To show the temporal trends of tropospheric ozone in Bangladesh. 


\section{MATERIALS AND METHODS}

A pot experiment was conducted with following study procedure :

\section{Cultivation of white clover}

Two white clover (Trifolium repens cv. Regel, genotypes NC-S and NC-R) cuttings were collected from ICP Vegetation Coordination Centre, UK. They were at first established in small pots (1 litre) grown in glass house condition in Bangladesh Institute of Nuclear Agriculture, Mymensingh on April 15, 2007 and then transferred to main field experiment in the Field Laboratory of Dept. of Environmental Science, Bangladesh Agricultural University, Mymensingh on May 13, 2007 in 15 litre plastic pots and they were grown in well. The recommended dose of fertilizers and intercultural operations were practiced as prescribed as in the standard protocol. Each cultivar was replicated in to twenty.

\section{Measurement of tropospheric ozone}

Ozone was measured by passive sampler at 28 days interval. Passive sampling is an inexpensive, reliable and simple ozone measurement technique. The passive ozone samplers were hanged in the field $3 \mathrm{~m}$ above from ground to measure the ozone concentration in the elevated level. During measurement the gas molecules diffuse into the sampler through the grey net.

\section{Measurement of metrological data}

The temperature and relative humidity was measured using Tinytag. The Tinytag hangs in the lower part of a tube, with the upper part of the tube being black and the lower part being either white or protected by a reflective cover (e.g. aluminium foil). The air will warm in the upper black part of the tube and rise, which will enable new air coming in from below. Alternatively, use a Stevenson screen if available or a simple arrangement with a shield made of aluminium foil through which air can pass, but within which the Tinytag is protected against direct sunlight. Data on total sunshine hour was collected from the weather station of Bangladesh Agriculture University, Mymensingh.

\section{Assessment of visual ozone injury}

Assessment of each plant (NC-S) for ozone injury every weekly indicated by the percentage of injured leaves using the following scale :

\section{Injury scoring system}

0 : No injury

1 : Very slight injury, occurrence of the first symptoms

2 : Slight injury, 1-5\% of the leaves with slight injury

3 : Moderate injury, 5-25\% of the leaves with injury

4 : Heavy injury, $25-50 \%$ of the leaves injured

5 : Very heavy injury, $50-90 \%$ of the leaves injured

6 : Total injury, $90-100 \%$ of the leaves are injured 
The plant biomass (forage : leaves, flowers and stolon) at the height of $7 \mathrm{~cm}$ above the soil surface were harvested at first on June 6,2007 . The $2^{\text {nd }}, 3^{\text {rd }}$ and $4^{\text {th }}$ harvests were done on July 8, August 5, and September 2, 2007 respectively at 28 days interval. The fresh plant materials were oven dried at $70^{\circ} \mathrm{C}$ for 72 hours and then their dry weights were taken. After collecting the data, it was correlated with ozone concentrations to know the yield losses in white clover by tropospheric ozone.

\section{RESULTS AND DISCUSSION}

The monthly mean ozone values collected at 28 days interval from passive ozone sampler during April to August 2007 and the results were presented in Table 1, where it was found that the ozone concentration ( $\mathrm{ppb}$ ) was increased gradually with time. During the study period temperature and relative humidity were measured using Tinytag. The data of total sunshine was also collected from the weather station of Bangladesh Agricultural University. All of those data are shown in Fig. 1. The impact of temperature on ozone concentration is shown in Fig. 2.

Table 1. Tropospheric ozone concentrations $(\mathrm{ppb})$ at 28 days mean in BAU farm area

\begin{tabular}{cc}
\hline Month & Mean ozone concentrations $(\mathrm{ppb})$ at 28 days \\
\hline April 2007 & 29 \\
May 2007 & 35 \\
June 2007 & 49 \\
July 2007 & 28 \\
August 2007 & 61 \\
\hline
\end{tabular}

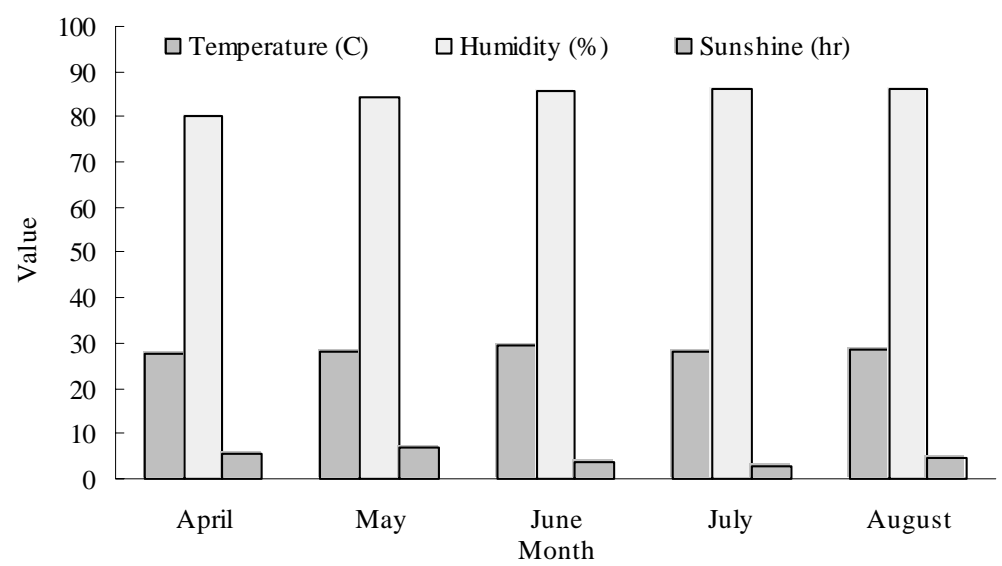

Fig. 1. Meteorological data in the experimental fields

The data shown in Table 1 revealed the range of plant biomass and mean values in both genotypes in different harvests. The minimum plant biomass was found as $0.28 \mathrm{~g} / \mathrm{plant}$ in the $1^{\text {st }}$ harvest and the maximum value was $22.346 \mathrm{~g} /$ plant in the $4^{\text {th }}$ harvest by the 
ozone resistant clover genotype (NC-R). The mean plant biomass values showed that the ozone sensitive genotype resulted in comparatively lesser vegetative growth than the resistant one in every harvest. But the plant biomasses were found gradually higher with the later harvests in both the genotypes (Table 2). The ozone susceptible cultivar generally produced comparatively less biomass than the resistant one at every harvest (Table 2). A 5\% reduction in biomass of the NC-S biotype relative to that of the NC-R biotype was associated with an AOT40 of $3.06 \mathrm{ppm} / \mathrm{h}$, and ozone fluxes to the NC-S biotype, accumulated using $40 \mathrm{ppb}$ as a threshold of 2.99 (ANN) and 3.09 (MA) mmol m2 over a period of three months (Mills et al., 2003).

The effect of ozone concentration on plant biomass ratio was shown in Fig. 3. Biomass ratio (NC-S/NC-R ratio) was gradually decreased with the increasing ozone concentrations in the troposphere. Biomass ratio of a 28 day growth period seems to be affected not only by the ozone levels in that same period, but also by ozone levels in the previous ones (De Marco et al., 2003).

Table 2. Dry weight and biomass ratio of clover plant in different harvesting period

\begin{tabular}{l|c|c|c|c|c}
\hline \multirow{2}{*}{$\begin{array}{c}\text { Harvesting } \\
\text { period }\end{array}$} & \multicolumn{4}{|c|}{ Plant biomass (g/plant) } & \multirow{2}{*}{$\begin{array}{c}\text { BM (NC- } \\
\text { S/NC-R) }\end{array}$} \\
\cline { 2 - 5 } & Ozone sensitive (NC-S) & \multicolumn{2}{c}{ Ozone resistant (NC-R) } & \multirow{2}{*}{ /Nean \pm SE } & \\
\cline { 2 - 5 } & Range & Mean \pm SE & Range & $1.387 \pm 3.906$ & 0.71 \\
\hline Ist harvest $^{\text {2nd }}$ harvest & $0.31-2.70$ & $0.980 \pm 1.859$ & $0.28-4.50$ & $5.207 \pm 5.981$ & 0.58 \\
$3^{\text {rd }}$ harvest & $0.33-8.30$ & $3.007 \pm 2.832$ & $1.03-16.68$ & $15.932 \pm 3.93$ & 0.56 \\
$4^{\text {th harvest }}$ & $4.70-16.40$ & $8.992 \pm 11.20$ & $8.10-21.18$ & $22.346 \pm 4.23$ & 0.55 \\
\hline
\end{tabular}

$\mathrm{BM}=$ Biomass ratio (NC-S/NC-R)

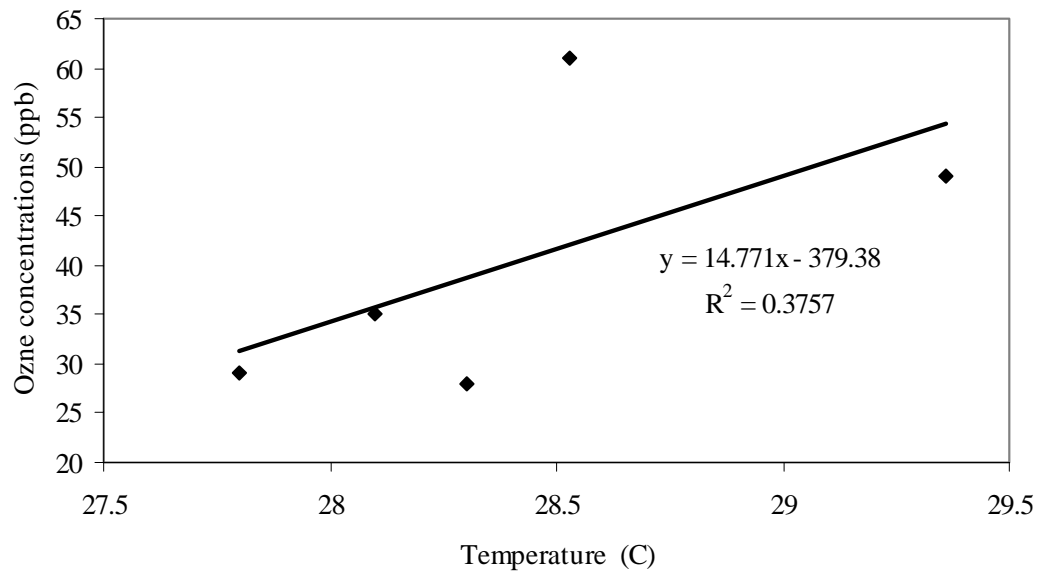

Fig. 2. Effects of temperature on ozone formation in the troposphere 


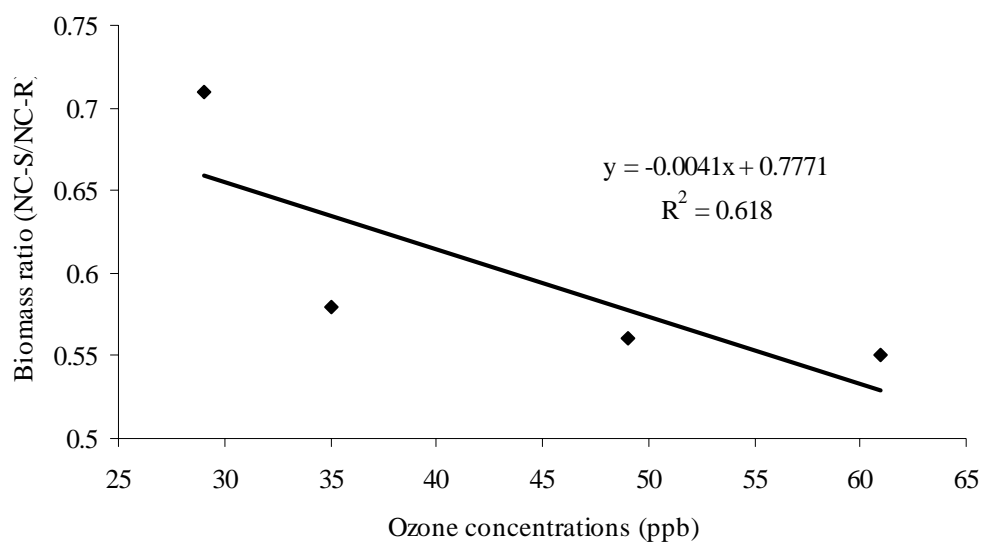

Fig. 3. Effects of tropospheric ozone on biomass ratio of white clover

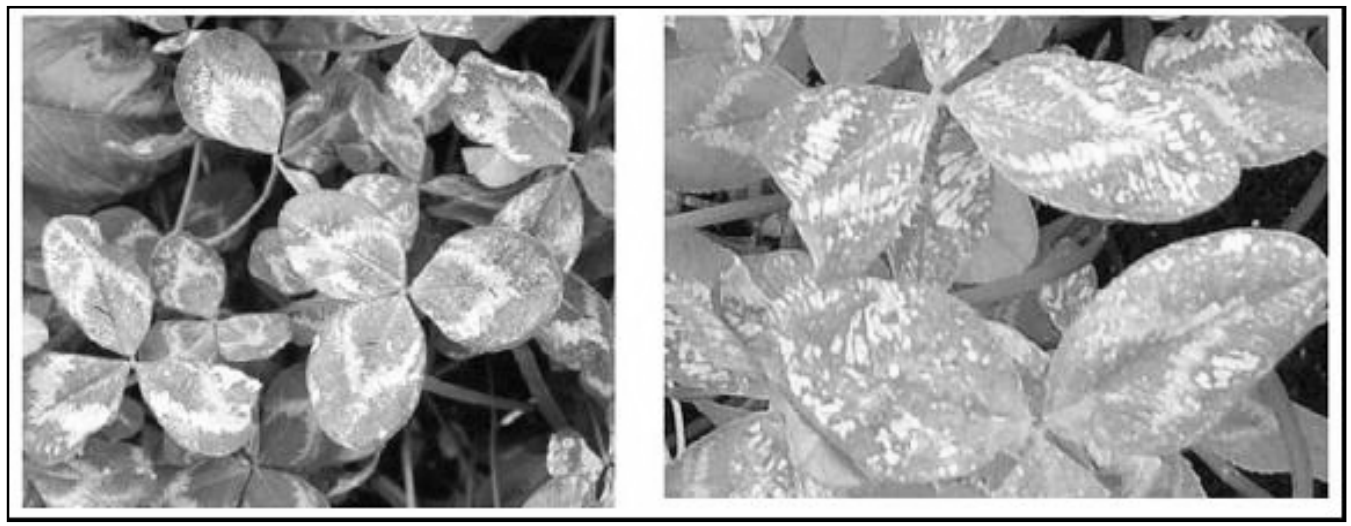

Fig.4. Typical ozone injuries on white clover leaves
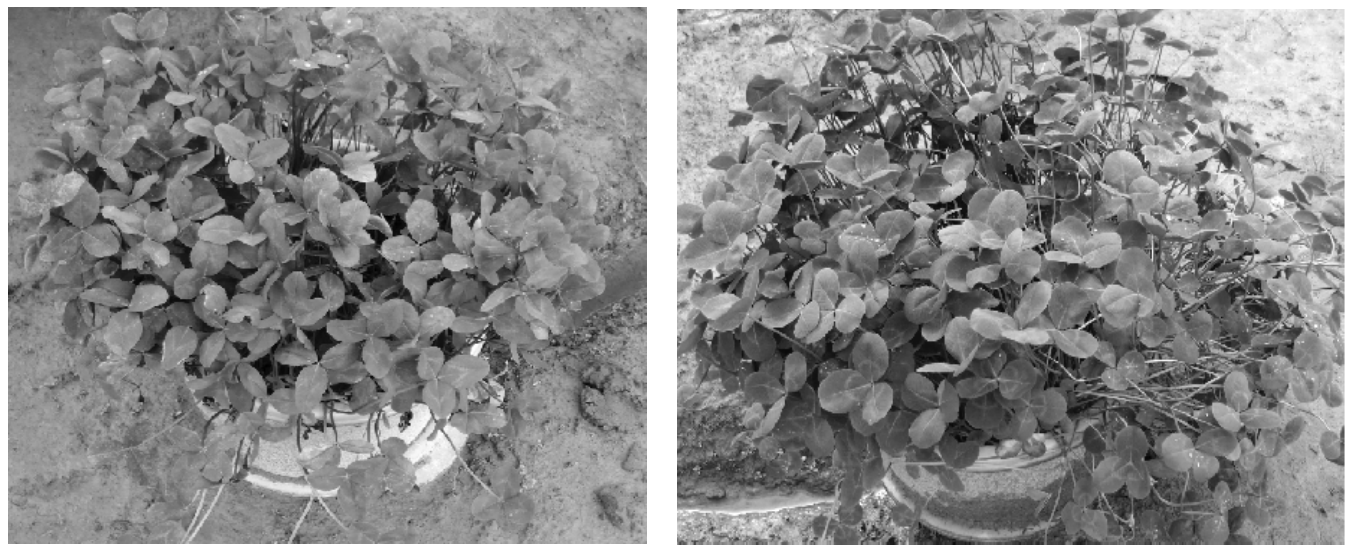

Fig. 5. Healthy ozone resistant white clover plant 
Table 3. Visual in jury in different harvesting period

\begin{tabular}{l|c|c|c}
\hline \multicolumn{1}{c}{ Harvesting period } & Ozone injured plant (NC-S) & Very slight injury & Slight injury \\
\hline Ist harvest $^{\text {nd }}$ harvest & $50 \%$ & $60 \%$ & $40 \%$ \\
$2^{\text {rd }}$ harvest & $55 \%$ & $60 \%$ & $40 \%$ \\
$4^{\text {th }}$ harvest & $45 \%$ & $40 \%$ & $60 \%$ \\
\hline
\end{tabular}

Very slight injury $=U p$ to $1 \%$ injured leaves among injured plant; Slight injury $=U p$ to $1 \%$ injured leaves among injured plant

The visual injury symptom appeared in the ozone sensitive genotype (NC-S) as very slightly (up to $1 \%$ injured leaves) to slightly (15\% injured leaves) with 50\%, 55\%, 45\% and $55 \%$ ozone injured plant from $1^{\text {st }}, 2^{\text {nd }}, 3^{\text {rd }} 4^{\text {th }}$ harvesting respectively (Table 3 and Fig. 4). The resistant cultivar showed no visual injury symptom (Fig. 5).

\section{CONCLUSION}

The ozone concentrations in troposphere increased gradually with time. So, routine research is essential to protect Bangladesh against the bad impact of global warming. The study was conducted on only white clover, which is very recognized ozone sensitive but not our native plant. Hence more study on local plant will be needed to conduct.

\section{RECOMMENDATIONS}

1. Emissions of $\mathrm{CH}_{4}, \mathrm{NO}_{2}$ and $\mathrm{CO}$ from vehicles should be reduced.

2. Use of new vehicles may be encouraged to avoid higher exhausts.

3. Air filter in the vehicles and brick fields may be introduced.

4. Campaign of tree plantation should be increased, which has enormous potentiality to reduce Global temperature.

\section{ACKNOWLEDGEMENT}

It is highly acknowledged to the Ministry of Science and Information \& Communication Technology, Govt. of the Peoples Republic of Bangladesh for releasing fund for the study.

\section{REFERENCES}

Agrawal, M. 2003. Air pollution impact on vegetation in India. In: Emberson, L. D., Ashmore, M. R., Murray, F. (Eds.), Air Pollution Impacts on Crops and Forests: a Global Assessment. Imperial College Press, London, UK. pp. 165-187.

Astorino, G., Margani, I., Tripodo, P., Manes, F. 1995. The response of phaseolus vulgaris L. cv. Lit. to different dosages of the anti-ozonant ethylenediurea (EDU) in relation to chronic treatment with ozone. Plant Sci., 111 : 237-248.

Bender, J., Bergmann, E., Weigel, H. J. 2003. Multi-year experiments on ozone effects on seminatural vegetation: implications for the development of critical levels. UNECE workshop report. IVL report B 1523. IVL Swedish Environmental Research Institute, Gothenburg, Sweden. 
Benton, J., Fuhrer, J., Gimeno, B. S., Skärby, L. Sanders, G. 1995. Results from the UN/ECE ICPCrops indicated the extend of exceedance of the critical level of ozone in Europe. Water, Air, and Soil Pollution, 85 : 1473-1478.

Chameides, W. L., Kasibhata, P. S., Yienger, J., Levy, H. 1994. Growth of continental scale metroplexes, regional pollution and world food production. Sci., 264, 74-77.

De Marco, A., Fagnano, M., Belgiovine, N., Capogna, F., Daffinà, R., De Bonfils, A., Fiorini, R., Forlani, A., Fumagalli, I., Giannini, M. A., Manes, F., Martignon, G., Merola, G., Mignanego, L., Piccolo, R., Postiglione, L., Racalbuto, S. I, Vialetto, G., Vitale, M. 2003. Ozone critical levels and effects on plants in Italy. UNECEF workshop report. IVL report B 1523. IVL Swedish Environmental Research Institute, Gothenburg, Sweden.

Ashmore, M. R. Davison, A. W. 1996. Towards a critical level of ozone for natural getation. In: Critical levels for ozone in Europe: Testing and finalizing the concepts. UN/ECE workshop report.

Fuhrer, J., Grandjean, Grimm, A., Tschannen, W., Shariatmadari, H. 1992. The response of spring wheath (Triticum aestivum L.) to ozone at higher elevations. Changes in yield, yield components and grain quality in response to ozone flux. New Phytol. 121 : 211- 219.

Fuhrer, J., Skorby, L., Ashmore, M. R., 1997. Critical levels for ozone effects on vegetation in Europe. Environmental Pollution, 97 : 91-106.

Mills, G., Bueker, P., Hayes, F., Emberson, L., Werner W., Gimeno, B., Fumagalli, I., Köllner, B., Manes, F., Pihl Karlsson, G., Soja, G., Vandermeiren, K. 2003. Developing ozone flux-effect models for white clover from the ICP vegetation ambient air monitoring experiment. UNECE workshop report. IVL report B 1523. IVL Swedish Environmental Research Institute, Gothenburg, Sweden.

Mills, G., Holland, M., Buse, A., Cinderby, S, Hayes, F., Emberson, L., Cambridge, H., Ashmore, M., Terry, A. 2003. Introducing response modifying factors into a risk assessment for ozone effects on crops in Europe. UNECE Workshop Report. IVL report B 1523. IVL Swedish Environmental Research Institute, Gothenburg, Sweden. 